\title{
LATIN AMERICA IN GLOBAL HISTORY: AN HISTORIOGRAPHIC OVERVIEW
}

América Latina na História Global:

uma visão historiográfica

América Latina en la Historia Global:

una visión Historiográfica

DIEGO OLSTEIN

http://dx.doi.org/10.1590/S2178-14942017000100014

Diego Olstein é PhD em História pela Universidade Hebraica de Jerusalém (Israel) e professor de História da Universidade de Pittsburgh (Estados Unidos) (holstein@pitt.edu). 


\begin{abstract}
World history can be arranged into three major regional divergences: the 'Greatest Divergence' starting at the end of the last Ice Age (ca. 15,000 years ago) and isolating the Old and the New Worlds from one another till 1500; the 'Great Divergence' bifurcating the paths of Europe and Afro-Asia since 1500; and the 'American Divergence' which divided the fortunes of New World societies from 1500 onwards. Accordingly, all world regions have confronted two divergences: one disassociating the fates of the Old and New Worlds, and the other within either the Old or the New World. Latin America is in the uneasy position that in both divergences it ended up on the 'losing side.' As a result, a contentious historiography of Latin America evolved from the very moment that it was incorporated into the wider world. Three basic attitudes toward the place of Latin America in global history have since emerged and developed: admiration for the major impact that the emergence on Latin America on the world scene imprinted on global history; hostility and disdain over Latin America since it entered the world scene; direct rejection of and head on confrontation in reaction the former. This paper examines each of these three attitudes in five periods: the 'long sixteenth century' (1492-1650); the 'age of crisis' (1650-1780); 'the long nineteenth century' (1780-1914); 'the short twentieth century' (1914-1991); and 'contemporary globalization' (1991 onwards).
\end{abstract}

KEY WORDS: Global History, Latin America, historiography, Great Divergence, globalization.

\title{
RESUMO
}

A história mundial pode ser organizada em três grandes divergências regionais: a "Maior Divergência" a partir do final da última Era do Gelo (cerca de 15.000 anos atrás), que isolou o Velho e o Novo Mundo até 1500; a "Grande Divergência", bifurcando os caminhos da Europa e Afro-Ásia desde 1500; e a "Divergência Americana", que dividiu as fortunas das sociedades do Novo Mundo a partir de 1500. Assim, todas as regiões do mundo enfrentaram duas divergências: uma desassociando os destinos dos Mundos Velho e Novo, e a outra dentro do Velho ou do Novo Mundo. A América Latina encontra-se na difícil posição de, em ambas as divergências, terminar no "lado perdedor". Como resultado, uma historiografia contenciosa da América Latina desenvolve-se desde o momento em que foi incorporada a um mundo mais amplo. Desde então, emergiram e desenvolveram-se três atitudes básicas em relação ao lugar da América Latina na história global: admiração pelo grande impacto que o surgimento da América Latina no cenário mundial imprimiu na história global; Hostilidade e desprezo pela América Latina desde sua entrada no mundo; Rejeição e confrontação direta na reação ao cenário anterior. Este artigo examina cada uma dessas três atitudes em cinco períodos: o "longo século XVI" (1492-1650); A "era das crises" (1650-1780); "O longo século XIX" (1780-1914); "O curto século XX" (1914-1991); e a "globalização contemporânea" (1991 em diante).

Palavras CHAVE: História Global, América Latina, historiografia, Grande Divergência, globalização.

\section{RESUMEN}

La historia del mundo puede organizarse en tres grandes divergencias regionales: La "Mayor Divergencia" a partir de finales de la última Edad de Hielo (hace unos 15.000 años) aislando el Viejo y el Nuevo Mundo hasta 1500; la "Gran Divergencia" que bifurca los caminos de Europa y Afro-Asia desde 1500; y la "divergencia americana", que dividió las fortunas de las sociedades del Nuevo Mundo desde el 1500 en adelante. En consecuencia, todas las regiones del mundo han enfrentado dos divergencias: una disociando los destinos del Viejo y del Nuevo Mundo, y el otro dentro del Viejo o del Nuevo Mundo. La América Latina se encuentra en la inquietante posición de que, en ambas divergencias, terminó en el "lado perdedor". Como resultado, una historiografía contenciosa de América Latina evolucionó desde el momento en que se incorporó al mundo más amplio. Desde entonces han surgido y desarrollado tres actitudes básicas hacia el lugar de América Latina en la historia global: la admiración por el impacto mayor que la emergencia en América Latina en la escena mundial imprimió en la historia global; Hostilidad y desprecio hacia América Latina desde que entró en escena mundial; y el rechazo directo en la reacción con el escenario precedente. Este artículo examina cada una de estas tres actitudes en cinco períodos: el "largo siglo XVI" (1492-1650); La "era de la crisis" (1650-1780); "El largo siglo XIX" (1780-1914); "El corto siglo XX" (1914-1991); Y "globalización contemporánea" (1991 en adelante).

Palabras Clave: Historia Global, América Latina, historiografía, Gran Divergencia, globalización. 


\section{INTRODUCTION}

(1 When Pizarro and Atahuallpa met at Cajamarca, why did Pizarro capture Atahuallpa and kill so many of his followers, instead of Atahuallpa's vastly more numerous forces capturing and killing Pizarro?... How did Pizarro come to there to capture him, instead of Atahuallpa's coming to Spain to capture King Carlos I?" With these rhetorical questions, Jared Diamond (1997: 74) underscores one of the greatest concerns of world history: the 'greatest divergence' between the development of Eurasia and America. His explanation, in a nutshell, stresses the lack of large mammals in America, the larger variety of plant species in Eurasia, and the geographical disposition of the continents (east-west axis for Eurasia; northsouth axis for America) that enhanced or prevented, respectively, the diffusion of products and germs. These preliminary advantages amplified by division of labor and specialization resulted in a huge gap between the Old and New Worlds represented by guns and steel. Attention to a second 'great divergence' was to follow, as Kenneth Pomeranz (2000) addressed the divergent path of development within Eurasia. In this account, Europe moved ahead due to a large series of intertwined factors including the legacies of the feudal past and the richness of subsoil in coal, as well as the combination of maritime trade with naval power and collaboration between entrepreneurs and states, and finally, the exploitation of African slaves and American resources.

To these divergences between the Old World and the New, as well as that within Old World societies, a third major one can be added. This is the great divergence between North and Latin America; the 'American divergence.' Although the harvest of global history from the last two decades does not offer yet a systematic account of this third divergence as its main subject, many authors have tackled it in the past, advancing diverse arguments. For Louis Hartz (1964) timing was the key: the arrival of a medieval feudal 'fragment' in Latin America sealed its historical course, as opposed to the fate of the British North America created by a capitalist modern 'fragment.' Cultural legacies as well as historical ties between metropolises and colonies were frequently fostered as causal explanations for the divergence. According to James Lang (1975), the declining power of the Cortes in Spain, as opposed to the rising power of the Parliament in England, together with the territorial nature of the Spanish colonial enterprise as opposed to the 
commercial emphasis of the English, amongst various differences, were behind the diverging fates of North and Latin America. This set of explanations even reached cultural essentialist extremes in a work by Claudio Véliz (1994) who looked at a series of dichotomies, confronting Catholic with Protestant ethics, centralist with federalist political systems, mestizaje with the domination of a single race, Gemeinschaft versus Gesel/schaft, failure and success. American divergence from these last perspectives appears encoded in Anglo-Saxon and Latin cultures. Whether these are timing, historical ties, cultural legacies, or even essentialist traits, all these explanations point towards the European side of the Atlantic as the reason for the American divergence. Anthony Pagden went in the opposite direction to suggest that the sources of this divergence reside in the land of destination, not departure. In other words, densely populated, wealthy, urbanized, and politically involved areas generated the ambition and provided the resources for tight colonial control. By contrast, sparsely populated areas without valuable resources at their disposal, kept profits low and reduced the motivation to develop centralized colonization, paving the way instead to local and autonomous initiatives. Out of these constraints in the loci of arrival, two different types of empires and later nation-states were to emerge, regardless of the cultural and historical luggage brought from the Old World (Pagden, 1995). This reasoning was stressed further by J. H. Elliott (2002: 240) in a contra-factual exercise in which having Columbus serve Henry VII reversed the paths of the English and Spanish Empires.

Nevertheless, the fact remains that there are three major divergences in world history. One between the trajectories of the Old and New Worlds, the 'Greatest Divergence,' another within the fates of societies in the Old World, the 'Great Divergence,' and a third line dividing the fortunes of New World societies, the 'American Divergence.'

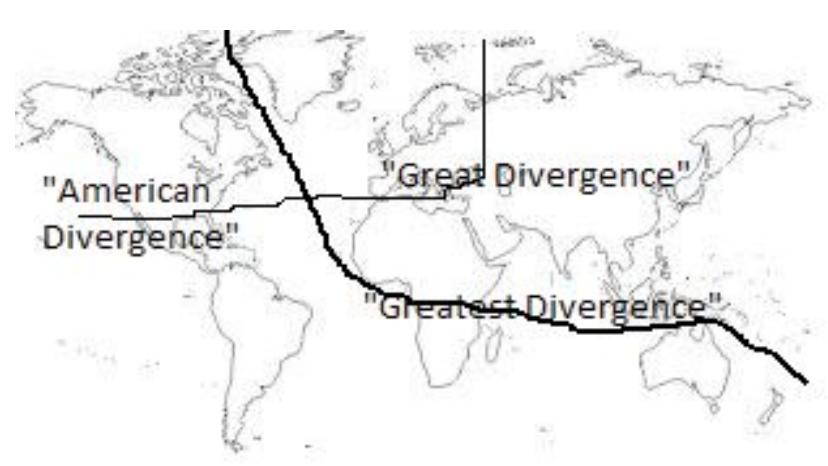

All world societies have thus confronted two 'challenges of divergence' according to this scheme, one between the Old and New Worlds, and the other within either the Old or the New World. Latin America is thus in the uneasy position that in both 'challenges of 
divergence' it ended up on the 'losing side'. With this broad scenario in mind we are to expect a contentious historiography from the very moment that Latin America was incorporated into modern global history onwards.

Applying Occam's razor, the present essay portrays three basic attitudes towards Latin America's place in global history. The first attitude is one of admiration for the great impact that the appearance of Latin America on the world scene imprinted on global history. The second attitude is one of hostility and disdain towards Latin America since it entered the world scene. The third is a direct reaction, confrontation, and rejection of the former attitude. Each of these three attitudes can come either from outside or inside Latin America as the first attitude does. However, the second attitude is more prone to coming from the outside and the third from the inside. This paper follows the tracks of these three attitudes during five well established historical stages: the 'long sixteenth century' (1492-1650), the period of conquest and colonization by the Iberian powers; the 'age of crisis' (1650-1780), a period of decline of Iberian might and the incorporation of Latin America in a broader European and global context; 'the long nineteenth century' (17801914), a period of major transformations worldwide which tightened ties with Latin America; and 'the short twentieth century' (1914-1991), a century of major conflicts, confrontations, and ideologies. Finally, the last two decades of 'current globalization' in which a new global consciousness emerged, including the consolidation of global history, is also examined, including looking back at some preceding milestones in historiography.

\section{THE 'LONG SIXTEENTH CENTURY' (1492-1650): A HIGHLY CONTROVERSIAL OPENING}

F rom the very beginning, reaching the Americas, more precisely several regions in the continent later known as Latin America, was perceived as a major turning point in world history. Francisco López de Gómara (1941) stated in 1551 that the discovery of America represented the most important event since the creation of the world, apart from the revelation and resurrection of its creator. In his 1569 Historia General de las Cosas de Nueva España Bernardino de Sahagún (2000) added that the discovery of America revealed concealed truths. Pedro Cieza de León (1998) combined both arguments, although in reference to Perú rather than México, by writing that the discovery of America was indeed the greatest event in secular history and that God's permission to find it was a major revelation after keeping this wonderful world hidden for so long.

This sense of revelation raised voices of pride and accomplishment, as in the Report on the Discovery of Peru by Francisco Xerez (1985), in which the author rhetorically asked: 
"When has it ever happened, either in ancient or modern times, that such amazing exploits have been achieved? Over so many climates, across so many seas, over such distances by land, to subdue the unseen and unknown? Whose deeds can be compared with those of Spain?" Then came the reply: "Not even the ancient Greeks and Romans." It also led to a missionary effort, since Queen Isabella had ordered in her Will, in compliance with Pope Alexander's bull Inter Caetera, that Indians be treated with respect and dignity. Efforts to build churches and establish missions continued up to Philip II.

However, from a mundane perspective, and as recognition that native rights were not enforced, radical criticism as well as explicit declarations of guilt and shame were also made. The Dominican friar Bartolomé de las Casas' (1994) description, and probable exaggeration, of the crimes perpetrated by the Spaniards in New Spain, particularly in Hispaniola, in his Brevisima relación de la destrucción de las Indias is the major example of this critical stance. In addition, the School of Salamanca, a group of theologians and jurists, challenged the legitimacy of the Spanish conquest on legal grounds. Francisco de Vitoria rejected, for example, the claim of voluntary submission or conversion on the part of the Indians. Yet he defended the right of the conquerors not only to propagate their faith, but also to dwell on the land and trade in them. As for expressions of guilt and shame, Mansio Serra Leguizamon's account of the conquest of Perú is a case in point. In his account he portrayed the Indians as initially free of crime and greed. This description is in diametric opposition to the way in which Spaniards are portrayed, who appeared as thieves, rappers, perpetrators of destruction, and ultimately as responsible for making the Indians evil people. Similar reports were written by Matias Paz, Zumarraga Mendieta, and Vasco de Quiroga, amongst others (Vitoria, 1967).

However, disruption of Indians' lives and rights resulted not only in criticism and shame but also in justification and apology. With his De rebus hispanorum gestis ad Novum Orbem Mexicumque, Juan Ginés de Sepúlveda (1987) became the champion of imperialist selfrighteousness. In De justis belli causis apud indios, he elucidates the principles of the just war, accordingly to which a superior civilization must subdue an inferior one in order to civilize it, convert it to Christianity, and by so doing equaling it to that of their conquerors. Cannibalism and human sacrifice were advanced by Sepúlveda as proofs for Indians' lack of civilization.

These opposite views ended up colliding in 1550 in a debate in front of a royal junta at Valladolid. The debate was theoretically oriented, with Sepúlveda and Las Casas offering different interpretations of Aristotle's concept of barbarianism and natural slavery, and to what extent these concepts applied or not to the Indians. Indians' capability to adopt Christianity without coercion was another central dimension of the Valladolid debate. The stalemate between these positions unfolded in the Spanish conquests amidst statutes envisioned to 
protect the Indians, such as the 'Ordinances Concerning Discoveries' issued in 1573 and the 'Recompilation of the Laws of the Indies' later in 1681 (Tyler, 1980), and local non-compliance with these.

This wide spectrum of attitudes ranging from revelation and triumphalism, rejection and shame, reassurance and self-rightness was perceived differently from the Indians' point of view. Spanish triumphalism appears as shock and dismay in the writing of native chroniclers, whose descriptions showed that charging horses, metal armor, steel swords, and artillery terrorized them. The conquerors' shame appears in Indian accounts as contempt for the greedy people scrambling for gold "like pigs" (León Portilla, 1962).

The Indians were not alone in vilifying the Spaniards. Several European writers, based on first hand contact with the New World or relying upon other accounts, especially Las Casas' Brevissima Historia (1994) and Theodor de Bry's (1992) engravings depicting Spanish atrocities, developed a critical stance towards the Spanish conquest of the Americas. Girolamo Benzoni (1519-1570?) represents the first option as he described his own experiences in the book Historia del Mondo Nuovo (1565). Benzoni (1967) stressed the atrocities perpetrated by the Spaniards and their hypocritical Christian behavior which prevented the Indians from fully embracing Christianity. In relation to the second option, writing about the New World without ever having visited it, one example is the Essais (1588) of Michel de Montaigne (1535-1592). There, he not only repeated the accusations of Spanish cruelty and hypocrisy, but also wrote sympathetically about the Indians, praising their refusal to succumb to tortures and remaining true to their beliefs. Moreover, far from being barbarians, their public roads and cities rivalled those of ancient Greece and Rome with their stateliness and beauty. In terms of military technology, however, he acknowledged Spanish superiority, but with a twist. Horses, armor, and canons, the pride of Spanish triumphalism and the cause of panic in Indian accounts, reappear in Montaigne's "On Cannibals" and "On Coaches" (1933), for diminishing Spanish triumphs by attributing them to the use of these weapons that the Indians had never seen before and could not match. The accumulation and reformulation of these kinds of arguments, many of which are coincidental with and partially relied upon De Las Casas' Brevissima Relación, were later to be known as the Black Legend, a defamatory anti-Spanish propaganda promoted by its traditional rivals, especially the English, Dutch, and French.

Black Legend propagandists were not the only ones to write about the New World during the long sixteenth century through the lenses of their well-established agendas. All the perspectives on the conquests and colonization of the areas that would become part of what now is known as Latin America had their stakes: Spanish triumphalism, the rejection of its results, and its justification; Indian consternation and grief confronting the collapse of 
their societies; European envy towards Spanish imperialist success. Out of these perspectives, three different attitudes emerged vis à vis what would become Latin America: admiration of its major impact on the history of the world; hostility, disdain, and patronizing; and direct rejection of and confrontation with the former. These attitudes proved to be a recurring feature in the way that Latin America was contextualized within global history. However, the particular contents sustaining these attitudes changed over time as the following sections show.

\section{THE 'AGE OF CRISIS' (1650-1780): MARGINAL AND CRUCIAL PLACES IN GLOBAL HISTORY}

$\mathrm{T}$ he Enlightenment adopted many of the prevailing themes of the Black Legend, such as cruelty towards Indians, a perverse desire for wealth, and characteristics of pride and sloth. For example, in his play Alzire (1736), set in Peru, Voltaire repeats the claims of Spanish cruelty in the Americas and their excessive desire for gold, as well as depicting the Indians as living in a state of innocence and natural humanity before the arrival of the Spanish (Voltaire, 2010). He made similar points in Candide (1759) whose plot takes place all across South America (Voltaire, 2003). However, not all enlightened scholars proved to be as sympathetic towards the New World and its peoples. In fact, the derogatory attitude towards what would become Latin America reached new dimensions during the Age of Enlightenment. Natural history is a case in point. As the 'father' of natural history during the second half of the eighteenth century, Georges-Louis Leclerc, Comte de Buffon (1828) advanced the thesis that nature is inferior in the New World in comparison with Eurasia. The lack of large mammals, the dense forests, and marsh odors were all presumably evidence for this, with the final result being that humans were also less virile. Cornelius Franciscus de Pauw (1771) was one of the scholars to follows in Buffon's steps. Considered to be an expert in the Americas despite never visiting the continent, he asserted that Indians were inferior to Europeans due to climatic and geographical conditions, discrediting in the process the Indians for devising the Mesoamerican calendar system. Moreover, these unfavorable conditions also impaired Europeans who moved into America, resulting in the decay of the Creoles. Natural history ended up permeating Hegel's philosophy of history (1975), in which climate, flora, and fauna, as well as the disposition of mountain ranges - from north to south instead east to west as in Eurasia - explain the marginality of America in world history.

Thomas Jefferson and James Madison took the lead in North America in refuting these arguments. In Latin America it was the friars once again, this time from the Jesuit order, who confronted this hostility. Juan Ignacio Molina accused de Pauw of degrading and discrediting 
America and countered his claims by writing a natural history of Chile showing the rich variety of species, the wealth underneath the soil, and the high standard of life of the inhabitants of America (Molina, 1987). Francisco Javier Clavijero also reacted to de Pauw's work, looking at history rather than nature. In his account, La Historia Antigua de México, the Indians are described as peaceful and good while the Spaniards are depicted as merciless conquerors. He also dealt with the Mesoamerican calendar system as something that originated locally (Clavijero, 1987).

In addition to animosity and sympathy, hostility and defense, the Americas continued to be a source of admiration due to their powerful impact on world history. Adam Smith made this point very clearly in 1776 when he published the Wealth of Nations and asserted that the discovery of America together with the circumnavigation of Africa represented the major turning points in the history of the world.

\section{III. 'THE LONG NINETEENTH CENTURY’ (1780-1914): REAFFIRMED FROM WITHIN, NEGLECTED FROM WITHOUT}

I nterestingly enough, it was not only the 'father' of economic liberalism who pointed to the discovery of the Americas as the major turning point in global history, but also the 'fathers' of communism. In the Communist Manifesto, Marx and Engels stated that the discovery of America and the circumnavigation of Africa represented the major turning points in the history of the world. This emphasis on the centrality of what would become Latin America in global history was entirely missing in the writing of subsequent macro-historians. In the writings of Toynbee (1988), Spengler (1991), Mumford, Dawson, and Sorokin we find a striking marginalization of Latin America's history in the global scene in both the pre-Columbian age and the modern period.

From a local perspective, the nineteenth century saw the reinvigoration of the third attitude, the confrontation of hostility and patronizing attitudes towards Latin America as a wave of independence movements swept across the region. In order to justify their rebellions, Latin-Americans emphasized the hardships of Spanish rule, which included overwhelming Spanish political control of America to the point that the residents felt they were powerless in their own communities. Examples of Spanish cruelty were readily found in the past, especially their treatment of native populations in the $16^{\text {th }}$ century. In this way, Creole Latin Americans were rejecting their own cultural heritage, and while disassociating themselves from their Spanish ancestry as descendants of the conquistadors they were placing themselves in the position of the helpless Indians during the time of the conquest, forced to suffer Spanish 
atrocities. This change of roles, succinctly defined as 'matricide' by Philip Powell (2008), fully justified the pursuit of freedom.

These issues were illustrated, for example, in the "Manifesto Directed to All Nations" (1816) from the Congress of the United Provinces of Rio de la Plata, in which the execution of Atahualpa, as well as of other leaders, the repression of the local population, and the destruction of cities and villages were all forcefully condemned (De Castro y Banos, 1819: 215-233). The theme of repudiation of Spain persisted even after many of the Latin American countries achieved independence. Jose Victorino Lastarria (1817-1888), a Chilean political and literary figure, argued in his book America (1867) that Latin America had succeeded in freeing itself from baleful Spanish influences and had set out on a new path towards progress, while declaring: "We are irresistibly directed to a life of reaction against the civilization of the mother country, and our progress depends on a rejection of our past." However, despite the romanticism in such declarations, the fact remains that rather than gaining independence, Latin America had only changed masters as the British Empire stepped into the Spanish vacuum. For all the potential contributions made by 'land of departure' and 'land of destination' approaches to the 'American divergence,' another important dimension of this was that the Thirteen Colonies gained their independence by detaching themselves from the emerging global empire by relying upon the support of the declining powers of France and Spain. The Latin American road to decolonization inverted this equation by expelling a declining empire by inviting a powerful emerging one to its shores. That is why Lord Canning, British foreign minister at the time, celebrated the occasion of Latin America's independence by stating: "Latin America is finally free, and it is ours!" (Lee, 2008) This advent of the British informal empire in Latin America would echo powerfully in the historiography of Latin America's place in global history and indeed in global history in general.

\section{IV. 'THE SHORT TWENTIETH CENTURY’ (1914-1991): NEW AND OLD GRIEVANCES COMING FULL CIRCLE}

\footnotetext{
C onfrontational voices continued to rise against the legacy of Spanish conquest and in praise of Indian societies. José Carlos Mariátegui synthesizes these views in his Seven Interpretative Essays on Peruvian Reality (2000), condemning large landowners for the stilted economy of the country and the miserable conditions of the indigenous peoples in the region, advancing traditional forms of collectivism practiced by the Indians as the solution. However, starting in the 1940s, the most insistent confrontational voices addressed the new forms of economic exploitation rather than the old colonial legacy. In research on Latin America's
} 
trade balance, Raúl Prebisch (1950) concluded that due to a larger elasticity of demand for manufactured goods, as opposed to primary products, as well as the imbalance of added value in favor of the former, the terms of trade between Latin America and the developed world were one of 'unequal exchange.' Under these terms of trade, trade partners were not equals like economically stronger states, trading relatively monopolized products and able to obtain surplus-value flowing from weaker states that traded under relatively free market conditions. These unequal exchanges, which were increasingly unbalanced and had resulted in an increasing polarization between core and peripheral states, had led Latin American societies into a new form of dependency in relation to the developed world. Dependency theory, the most outstanding contribution of Latin American social sciences, was born. A long list of scholars and thinkers developed and strengthened the theory, including Fernando Henrique Cardoso (1979), Enzo Faletto (1979), Theotonino dos Santos (1967), Silvio Frondizzi (1957), and Osvaldo Sunkel (1973). However, the single most far reaching publication which spread the dependency concept was Las Venas Abiertas de América Latína (The Open Veins of Latin America) by Eduardo Galeano (1973). The book offers a global history of Latin America from the colonial era up to the 1960's. Its main argument is that the region had been exploited since achieving formal independence, first by colonial empires (Spain and Portugal) and afterwards by imperialist states (mainly the UK and the US). Thus, the fates of Indian societies and of European offshoot societies were bundled together as a continuous history of exploitation. The 'Greatest divergence' and the 'American divergence' with their grievances appear side by side in this book, as in many dependency theory writings.

Dependency theory represented a new form of direct rejection of and confrontation with a newer patronizing view of Latin America: modernization theory. According to modernization theory a process of differentiation transformed traditional societies by creating new specialized institutions in the economic, political, cultural and social spheres. A series of preconditions in terms of values, institutions, and motivations were necessary for this transition to take place. Therefore, by meeting a set of preconditions and undergoing the process of differentiation, every society could move from the traditional stage toward modernization. Failure to do this would result in the inability of a particular society to meet the necessary conditions due to historical backwardness, in which case transference of technology, institutions, and values from modern (western) societies could put such a backward society on the path to modernization. Modernization theory understood each society in an enclosed fashion with possible corrective inputs from the outside. (Lipset, 1959: 69-105) Dependency theory confronted this assumption, viewing each society as shaped by the way in which it integrates with the world as a whole. Out of this framework and following very similar premises a new approach to social sciences 
and history followed dependency theory's footsteps: The world systems approach (Huntington, 1968).

The world systems approach accounted for the rise and spread of capitalism globally. It was originally conceived by Immanuel Wallerstein (1976) in his The Origins of the Capitalist World System (1974) and Andre Gunder Frank is his World Accumulation, 1492-1789(1978). The world system is portrayed from a Marxist perspective as an exploitative one, both within societies, i.e. 'surplus value' extracted from the working class by capitalists, and between societies as core capitalist ones take advantage of peripheral societies. The world system approach is also indebted to the Annales School for the notion of 'world-economy' (économiemonde) and its long cycles (fourteenth century Italian city-states, the seventeenth century United Provinces, nineteenth century Great Britain, and twentieth century United States) as described by Braudel (1992). But first and foremost, it seems that dependency theory is the predominant substrate underlying the world systems approach. Inter alia, the world systems approach and dependency theory share the understanding that any society is shaped by the way in which it interacts with other societies. In other words, the enclosed orientation of national histories is displaced by larger units of analysis. In this way, dependency theory contributed, through the world systems approach, to paving the way for forms of historical writing that go beyond national boundaries and which ultimately became global history. But not without important stepping stones having been laid first.

\section{V. 'CURRENT GLOBALIZATION’ (1991-2016): LATIN AMERICA AND GLOBAL HISTORY}

$\mathrm{T}$ he impact of the world systems approach, a further development of dependency theory, on the emerging field of world and global history can be illustrated by the ways in which world history was written before and after its imprint on one of the pioneers in this field, William Mc Neill. His The Rise of the West (1963) is organized by a principle of balance between civilizations (focusing on the Chinese, Indian, Middle Eastern, and Western civilizations). According to this principle, the rupture of balance between civilizations results in a challenge that stimulates transformations. Following this principle, the chronology is divided into three major periods: 3000-500 BCE, in which Middle Eastern civilization destabilized the balance through the agricultural revolution and birth of cities; 500 BCE - 1500 AD, characterized by relative stability among civilizations, despite being shaken by the diffusion of Hellenism, Indian culture, and rise of Islam; and 1500-1990 in which first Europe and then the West broke the equilibrium among civilizations through the impacts produced by the Ancien Régime and the 
twin revolutions (industrial and democratic). The underlying principle of homeostatic stability akin to functionalist sociology and modernization theory is in sharp contrast with McNeill's new synthetic book, The Human Web: a Bird's Eye View on World History (2003). Instead of enclosed civilizations, the basic building blocks in this second book are cross-boundaries networks. The interactions and exchanges in these networks, and not the disruption of balance between civilizations, constitute the fundamental process. In this new view the chronology of world history was also changed. A language revolution enabled the creation of networks that, nevertheless, were volatile until ca. 12,000 BP. After this, thicker networks evolved until the consolidation of 'metropolitan webs' around $6000 \mathrm{BP}$, with the emergence of cities. Over two thousand years, following the intermittent increase of flows and contacts, the 'Old World Web' spread across Eurasia and North Africa. The mastering of navigation around the Pacific Ocean led to the 'cosmopolitan web.' Finally, a century and a half ago, starting with the telegraph, this network began its electrification resulting in the current 'single global web.' The organizing principle of the web with its emphasis on interactions and exchanges, at least part of the time 'unequal,' is reminiscent of the world system.

Moreover, even before the emergence of Global History in the last two decades, the history of Latin America has been brought into contexts that are wider than the regional ones. Several theses, approaches, and themes have contributed to highlighting the significant impact of Latin America to histories that go far beyond the realm of the subcontinent, among them the concepts of the 'price revolution,' 'Columbian exchange,' and 'Atlantic history.' The 'price revolution' thesis, originally developed by Hamilton (1934), attributed the six-fold inflation in Europe during the long sixteenth century to the large influx of silver and gold arriving principally from Potosí and Zacatecas. These inflationary trends had far reaching consequences for the economies of Europe, crucially Spain and the Habsburg Empire, but also for the Ottoman Empire and China. The much debated price revolution thesis and more broadly the history of bullion have been receiving growing attention in the last two decades. This line of inquiry has been globally contextualized by insisting not only on the Atlantic flotilla carrying the precious load but also the Acapulco - Manila - Macao route and its repercussions. Arguably, it was this trade that was responsible for the first global 'price convergence' in the value of silver, therefore it was the first true globalization (Crosby, 1972) (Greene, 2009) (Flynn, 2004: 85-108).

The 'Columbian exchange' and subsequently the 'Magellan exchange' represent a second example of admiration for the major impact of what would become Latin America on the world scene. One can just to try to imagine Spain without tobacco, Italy without tomato sauce, Switzerland without chocolate, Romania without mămăligă (a meal based on corn flour), or Russia without potatoes, to realize the deep impact of the transference of produce 
from the Americas to Europe. This exchange also transformed the landscape the other way, as the fields of Canada and Argentina are unimaginable without wheat, and cowboys and gauchos are inconceivable except riding their horses and herding their cows. Moreover, it was the arrival of cassava in Africa and sweet potato in China to which the major demographic growth there is attributed.

Eventually, the interest in bullion shipping, exchanges in biota, and many other flows between the New World and the New, such as free and forced migrations, labor systems particularly slaves -, ideas, and political movements through the Atlantic Ocean resulted in the emergence of a wide unit of analysis, the Atlantic World. Since the mid-1980s, Bailyn has been organizing an annual international seminar at Harvard designed to promote scholarship in this field, supporting social and demographic studies. A large body of literature has evolved out of this approach (Bailyn, 1996: 19-44). By enlarging the unit of analysis beyond the boundaries of any single empire or future nation-state and emphasizing interregional contacts, flows, and networks, the Atlantic World approach also paved the way for the emergence of Global History. In fact, Atlantic History is an important part of Global History (Bailyn, 2005).

A major work in this category and especially in terms of the central place attributed to Latin America in the global scene is Imagined Communities by Benedict Anderson (1983). According to him, it was in Latin America that nationalism emerged, crossing the Atlantic eastwards and reaching the Old World. The roots of the transition from a world of empires up to the nineteenth century into a world of nation-states characteristic of the twentieth century are thus to be found in Latin America. This central role of Latin America in the political arena is reminiscent of the centrality that the world systems approach - echoing dependency theory, and before that the work of Marx and Smith - attributed to Latin America in the economic realm. Indeed, the modern world system envisioned by Wallerstein and Frank is geographically coincident with the Atlantic World and the triangular trade - encompassing Europe, America, and Africa - that linked much of the interaction within the Atlantic basin. In fact, both the world systems and Atlantic World approaches share several criticisms, ranging from the enclosed to the global scales of the historiographic spectrum. On the one hand, from an enclosed perspective (i.e. the history of a single empire, metropolis, or colony), these approaches are too expansive by intending to subsume both of the American continents, Africa and Europe, without seriously engaging with them. On the other hand, from a global perspective these approaches appear too narrow insofar they isolate the Atlantic rim from other oceanic rims and their respective networks. In the case of the world system approach the varieties of criticisms are even more extensive, including 'statist criticism' (i.e. the state appears entirely subsumed by economic forces rather than as an autonomous entity) (Evans, 1985), 
'culturalist criticism' (i.e. the cultural domain is relegated to a position of epiphenomenon) (Aronowitz, 1990), and 'Marxist criticism' (also known as the Brenner debate (Aston, 1985), which argues that the world systems approach privileges trade over production and prioritizes world markets over intra-societal class structure and conflict). All of these criticisms emerged alongside the actual formulation of the approach during the 1970's. However, it was in the last two decades of current neoliberal globalization that criticism of the world systems approach and, more to the point, its Latin American predecessor dependency theory, sharpened and strengthened.

Neoliberalism entered Latin America twice. First, during the last round of military dictatorships in the 1970's and much more powerfully during the 1990's under newly established democratic regimes. Accompanied by heavy repression, the first wave of neoliberalism was forceful and resulted in the banishment and even assassination of dependency theory thinkers. Symbolically enough, Las Venas Abiertas de América Latinawas banned by military dictatorships across the region. Its second wave in the region was far more consensual than coercive. This time it was not censorship that confronted dependency theory, but neoliberal globalization with its premises of 'states-out markets-in,' profound processes of privatization within each state, and free trade based on comparative advantages within the world economy. Rather than through censorship, Las Venas Abiertas was discarded in this round by broad segments of the public opinion as reflected in the Manual del perfecto idiota lationoamericano(Manual of the Perfect Latin American (diot) by Plinio Apuyelo Mendoza, Carlos Alberto Montaner, and Álvaro Vargas Llosa, which bluntly confronts Galeano's book (2000). Moreover, while this quarrel evolved in the pages of popular literature, a stronger blow to dependency theory was Fernando Henrique Cardoso's - a former leading dependency theorist and later president of Brazil - neoliberal policy and its justification. In contemporary Latin America, polarized between neoliberals and neo-populists, the latter stick to the premises of dependency theory, or at least its discourse, as demonstrated by Hugo Chávez's gift to Barack Obama of a copy of Las venas abiertas.

The age of current globalization is, therefore, a contested stage for dependency theory: Latin America's greatest contribution of to the social sciences, a perspective that placed Latin America in a key role in the history of the modern world, and an important moment through its application to other regions in the world and the formulation of the world systems approach - in the emergence of global history. Out of this contestation, several scholars have confronted the basic premises of dependency theory by re-contextualizing Latin America globally in a different way. That is the case of the debate of import-substitution versus 'open industrialization,' in which industrialization processes in Latin America are compared with 
those in East Asia. The selection of East Asia as a contrasting case to Latin America is devised to argue that emergent economies flourished due to foreign investment and liberalized trade and labor markets, rather than state protectionism and interventionism as envisioned by dependency theorists and structuralist economists (Maxfield, 1997) (Kohli, 2004).

In addition, the transition to democratic regimes encouraged a globally contextualized series of comparisons between Latin America and other emerging democratic regimes such as Greece, Portugal, and Spain (Baloyra, 1987). While the economic comparison with East Asia was devised to highlight the remarkable differences between the two regions, the political comparison between Southern Europe and Latin America stresses the crucial agreements between the two areas, such as the replacement of shaky democratic foundations by authoritarian dictatorships, and finally the move since the mid-1970's toward democratization, first in the Mediterranean, then in the Atlantic. Over time, this type of comparisons of transitions toward democracy have adopted a global scope (Ethier, 1990).

\section{CONCLUSION}

$\mathrm{L}$ atin America was left behind in both the 'greatest divergence' and the 'American divergence.' As these unfolded, approaches to Latin America involved attitudes of both hostility and sympathy. Over the centuries, these contradictory attitudes were indeed the two sides of the same coin, that of fitting Latin America into western standards. Opposing attitudes toward the region were in fact two alternative pathways to fostering the transformation of the region accordingly to ideals brought first from Europe and, since the twentieth century, from the United States. During the 'long sixteenth century' (1492-1650) the major concern has been evangelization. Bringing salvation to the souls of Indians and Christianity to the New World was the concern of both the self-righteous camp justifying the conquest and those defending the rights of the Indians. The religious goal and/or justification of salvation was replaced under the auspices of the Enlightenment by the secular aim and/or excuse of the ideal of progress, both during the 'age of crisis' (1650-1780) and 'the long nineteenth century' (1780-1914), again by those adopting and hostile as well as sympathetic attitudes toward the region and its peoples. During 'the short twentieth century' (1914-1991) the ideal of modernization took the lead as a particular formulation of the ideal of progress. Nowadays and during the last two decades of 'current globalization,' the promise has been successful integration in the global economy.

All of these goals were locally contested, from the mourning of the Indian chronicles, through the pro-independence Creoles, and up to the dependency theorists. More than 
externally imposed goals or deceptions, either in their sympathetic or hostile forms, and their local embracing or contesting responses, Latin America gained a central place in global history in the writing of early modern chroniclers marveling at the discovery and its implications, in the works of the founding fathers of Liberalism and Marxism, and in the historiography produced by two approaches developing since the 1970's and 1980's, world systems and Atlantic history respectively. Moreover, one of these approaches - world systems - emerged out of the major contribution made by Latin American scholars to Social Sciences, namely, dependency theory. Furthermore, the world systems approach is one of the informing pillars of global history as has been emerging for the last twenty years. Now is the time to see how global history will recontextualize Latin America in the global scene and how Latin American historians will make their own inroads into global history.

\section{BIBLIOGRAPHY}

ANDERSON, Benedict. Imagined communities: reflections on the origin and spread of nationalism. London: Verso, 1983.

ARONOWITZ, Stanley. The crisis in historical materialism: class, politics and culture in Marxist theory. Basingstoke: Macmillan, 1990.

ASTON, Trevor \& PHILPIN, C.H.E. The Brenner debate: agrarian class structure and economic development in pre-industrial Europe, Cambridge [Cambridgeshire], New York: Cambridge University Press, 1985.

BAILYN, Bernard. The idea of Atlantic history, Itinerario, 20-1, 1996, p. 19-44.

Atlantic history: concept and contours. Cambridge: Harvard University Press, 2005.

BALOYRA, Enrique (ed.). Comparing new democracies: transition and consolidation in Mediterranean Europe and the southern cone. Boulder: Westview Press, 1987.

BENZONI, M. Jeronimo. La historia del mundo nuevo, traducida por Carlos Radicati di Primeglio. Lima: Universidad de San Marcos, 1967.

BRAUDEL, Fernand. The perspective of the world. Trans. by Reynolds, S. Berkeley: University of California Press, 1992.

BUFFON GEORGES-LOUIS LECLERC, Comte de. Ouvres completes. Paris, 1828.

CARDOSO, Fernando Henrique \& FALETTO, Enzo. Dependency and development in Latin America. University of California Press, 1979.

CIEZA DE LEÓN, Pedro de. The discovery and conquest of Peru: chronicles of the New World encounter, edited and translated by Alexandra Parma Cook and Noble David Cook. Durham, NC: Duke University Press, 1998.

CLAVIJERO, Francisco Javier. Historia antigua de Mexico. México: Porrua, 1987.

CROSBY, Alfred. The Columbian exchange: biological and cultural consequences of 1492. Greenwood Press 1972. 
DE BRY, Teodoro. América, (1590-1634), edición Gereon Sievernich, traducción Adán Kovacsics. Madrid: Ediciones Siruela, 1992.

DE CASTRO Y BANOS, Pedro Ignacio. "Manifesto Directed to All Nations by the General Constituent Congress of the United Provinces of Rio de la Plata". In: Rodney, Caesar Augustus, Graham, John \& Funesp, Gregorio. The reports on the present state of the United Provinces of South America. London, 1819, pp. 215-233.

DE LAS CASAS, Bartolomé. Brevisima relación de la destrucción de las Indias, edición, introducción y notas de José María Reyes Cano. Barcelona, España: Planeta, 1994.

DE PAUW, Cornelius Franciscus. Recherches philosophiques sue les Américains. Berlin, 1771.

DE XEREZ, Francisco. Verdadera relación de la conquista del Perú, edición y estudio introductorio de María Concepción Bravo Guerreira. Madrid, Historia 16, 1985.

DIAMOND, Jared. Guns, germs, and steel: the fates of human societies. New York:W.W. Norton \& Co, 1997, p. 74.

DOS SANTOS, Theotonino. El nuevo carácter de la dependencia; gran empresa y capital extranjera. Santiago de Chile, Facultad de Ciencias Económicas, Universidad de Chile, 1967.

ELLIOT, J. H. Afterword. Atlantic History: A Circumnavigation. In: Armitage, David \& Braddick, Michael J. (eds.). The British Atlantic World. New York: Palgrave Macmillan, 2002, pp. 240-243.

ETHIER, Diane (ed.). Democratic transition and consolidation in Southern Europe, Latin America and Southeast Asia. Basingstoke: Macmillan, 1990.

EVANS, Peter, Rueschemeyer, Dietrich \& Skocpol, Theda (eds.). Bringing the state back in. Cambridge [Cambridgeshire], New York: Cambridge University Press, 1985.

FLYNN, Dennis \& Giráldez, A. Path dependence, time lags and the birth of globalisation: a critique of O'Rourke and Williamson, European Review of Economic History, 8-1, 2004, pp. 85-108.

FRANK, Andre Gunder. World accumulation, 1492-1789, Monthly Review Press, New York, 1978.

FRONDIZZI, Silvio. La realidad argentina: ensayo de interpretación sociológica, Buenos Aires: Praxis, 1957.

GALEANO, Eduardo. Open veins of Latin America; five centuries of the pillage of a continent, translated by Cedric Belfrage, Monthly Review Press, New York, 1973.

GREENE, Jack P. and Morgan, Philip D. (eds.). Atlantic history: a critical appraisal. Oxford: Oxford University Press, 2009.

HAMILTON, Earl. American treasure and the price revolution in Spain, 1501-1650. Cambridge, Massachusetts: Harvard University Press, 1934.

HARTZ, Louis, The founding of new societies: studies in the history of the United States, Latin America, South Africa, Canada, and Australia. New York: Harcourt, Brace \& World, 1964.

HEGEL, Georg Wilhelm Friedrich. Lectures on the philosophy of world history, translated by Johannes Hoffmeister. New York: Cambridge University Press, 1975.

HUNTINGTON, Samuel. Political order in changing societies. Yale University Press, 1968.

KOHLI, Atul, State-directed development: political power and industrialization in the global periphery. Cambridge, UK, New York: Cambridge University Press, 2004. 
LANG, James. Conquest and commerce: Spain and England in the Americas. New York:Academic Press, 1975.

LASTARRIA, José Victorino. La America. Gante, Impr. de E. Vanderhaeghen, 1867.

LEE, Stephen M. George Canning and liberal toryism, 1801-1827. Woodbridge, Boydell \& Brewer, 2008.

LEÓN PORTILLA, Miguel (ed.). The broken spears: the Aztec account of the conquest of Mexico, translated from Nahuatl into Spanish by Angel María Garibay K.; English translation by Lysander Kemp. Boston: Beacon Press, 1962.

LIPSET, Seymour Martin. Some Social Requisites of Democracy, American Political Science Review, 1959, 53-1, pp. 69-105.

LÓPEZ DE GÓMARA, Francisco. Historia general de las Indias. Madrid, Espasa-Calpe, s. a., 1941.

MAXFIELD, Sylvia and Schneider, Ben Ross (eds.). Business and the state in developing countries. Ithaca: Cornell University Press, 1997.

MCNEILL, William, The rise of the West; a history of the human community. Chicago:, University of Chicago Press, 1963.

MCNEILL, John and MCNEILL, William. The human web: a bird's-eye view of world history. New York: W.W. Norton \& Company, 2003.

MENDOZA, Plinio Apuleyo, MONTANER, Carlos Alberto \& VARGAS LLOSA, Alvaro. Guide to the perfect Latin American idiot, translated by Michaela Lajda Ames. Madison Books, 2000.

MOLINA, Juan Ignacio. Ensayo sobre la historia natural de Chile, traducción del Prof. Dr. Rodolfo Jaramillo. Santiago: Eds. Maule, 1987.

MONTAIGNE, Michel de. The essays, translation by John Florio. New York: The Modern library, 1933.

PAGDEN, Anthony. Lords of all the world: ideologies of empire in Spain, Britain and France c. 1500-c. 1850. New Haven, CT: Yale University Press, 1995.

POMERANZ, Kenneth. The great divergence. Princeton, N.J.: Princeton University Press, 2000.

POWELL, Philip Wayne. Tree of hate: propaganda and prejudices affecting United States relations with the Hispanic world. Albuquerque: University of New Mexico Press, 2008.

PREBISCH, Raúl. The economic development of Latin America and its principal problems. New York: United Nations, 1950.

SAHAGÚN, Bernardino de. Historia general de las cosas de Nueva España. México, D.F., Consejo Nacional para la Cultura y las Artes, 2000.

SEPÚLVEDA, Juan Ginés de. Historia del Nuevo Mundo, introducción, traducción y notas de Antonio Ramírez de Verger. Madrid: Alianza, 1987.

SPENGLER, Oswald. The decline of the West, English abridged ed. prepared by Charles Francis Atkinson. New York: Oxford University Press, 1991.

SUNKEL, Osvaldo. Past, present, and future of the process of Latin-American underdevelopment. Budapest: Center for Afro-Asian Research of the Hungarian Academy of Sciences, 1973. 
DIEGO OLSTEIN

TOYNBEE, Arnold. A study of history. London: Thames and Hudson, 1988.

TYLER, S. Lyman. Spanish laws concerning discoveries, pacifications, and settlements among the Indians: With an Introduction and the First English Translation of the New Ordinances of Philip II, July 1573, and of Book IV of the Recopilación de leyes de los reinos de las Indias, Relating to these Subjects. Salt Lake City, American West Center, University of Utah, 1980.

VÉLIZ, Claudio. The New World of the gothic fox: culture and economy in English and Spanish America. Berkeley: University of California Press, 1994.

VITORIA, Francisco de. Relectio de Indis o libertad de los Indios, edición crítica bilingüe por L. Pereña y J.M. Pérez Prendes. Madrid, C.S.I.C., 1967.

VOLTAIRE. Alzire: ou les Americains. Kessinger Publishing, 2010.

Candide. Barnes \& Noble Classics, 2003.

WALLERSTEIN, Immanuel, The modern world-system: capitalist agriculture and the origins of the European world-economy in the sixteenth century. New York: Academic Press, 1976. 